\title{
The Changing Meanings of Neighborhood in Modern Istanbul
}

DOI: $10.26466 /$ opus. 872573

\author{
* \\ Sezgi Durgun * \\ * Öğr. Gör. Dr., Marmara Üniversitesi, Siyasal Bilgiler Fakültesi, İstanbul/Türkiye \\ E-Mail: sezgi2005@gmail.com \\ ORCID: $0000-0002-6482-141 \mathrm{X}$
}

\begin{abstract}
Departing from the Ottoman-Turkish concept of mahalle (neighborhood) and its transformation, this article endeavors to discuss how the local people react to the socio-economic changes that came along the revitalization processes in Istanbul in the last 10 years. The study departs from a field work that has been conducted in Rasimpaşa neighborhood in Kadiköy, located at the Asian part of Istanbul, where there seems to be an ongoing process of revitalization, which started in 2010 with the partnership of The Foundation for the Protection and Promotion of the Environment and Cultural Heritage [ÇEKÜL] and Kadıköy Municipality. Rasimpaşa neighborhood constitutes a good example for old mahalle tradition since it preserved the Ottoman heritage and it is officially under the urban protection. Today it seems to preserve the characteristics of the "mahalle culture" that is embraced by the migrant families who came to Istanbul from Anatolian cities and who got localized here in time. Moreover, Rasimpaşa accommodates newcomers such as university students, international visitors (Erasmus students, upper middle-class artists, musicians, travelers). The question of the research has a simple focus: How do the local shopkeepers perceive the recent changes in the neighborhood and what are their reactions regarding the past present and future of neighborhood. it is assumed that the locals in Rasimpaşa would welcome the revitalization process that would increase the visitors/tourists/customers. According the findings of the field work most of the local shopkeepers perceive the process in a negative way due to the decay of traditional values as well as decay of old neighborhood lifestyle. Hence this study tries to address the social implications of the revitalization process by demonstrating how and why local people respond to this transformation.
\end{abstract}

Key Words: Neigborhood, İstanbul, Urban Revitalization, Rasimpaşa 


\section{Modern İstanbul'da Mahalle'nin Dönüşen Anlamları}

\section{Öz}

Makale, Türk ve Osmanlı kültüründeki mahalle kavramından yola çıkarak mahalle kavramının dönüşümünü ve son on yılda İstanbul'daki kentsel canlandırma projelerinin getirdiği sosyo-ekonomik değişimleri yerel esnafin gözünden görmeyi amaçlamıştır. Çalışmanın mekanı İstanbul'un Anadolu yakasinda bulunan Kadıköy Rasimpaşa mahallesidir. Bu mekanın seçilmesinin temel nedeni Rasimpaşa'nın Belediye ve Çevre ve Kültür Değerlerini Korumave Tanıtma Vakfi [ÇEKÜL] işbirliği ile 2010 yılında başlatılan canlandırma projesinin parçası olmasıdır. Rasimpaşa mahallesiOsmanlı mirasını koruması ve resmi olarak koruma altında olması nedeniyle dönüşen "mahalle" kavramı için iyi bir örnektir. Anadolu kentlerinden gelip zaman içinde burada yerleşik hale gelen göçmen aileler, mahalle kültürünün korunmasında önemli bir rol oynamıştır. Günümüzde Rasimpaşa'nın nüfusuna her geçen gün üniversite öğrencileri, dı̧̧ ülkelerden gelen gezginler, üst orta sınıfkentliler, sanatçıla reklenmektedir. Makalenin araştırmasorusu, mahalle sakinlerinin yaşadıkları canlandırma sürecini nasıl alglladıkları ve mahallenin geçmişi, bugünü ve geleceği hakkındaki görüşleridir. Araştırmada yöntem olarak saha çalışması ve derinlemesine görüşme tekniği kullanılmıştır Çalışmanın varsayımı belediye destekli canlandırma projesinin yerel ekonominin canlandıracağı ve yaşanan dönüşümün yerel esnaf tarafindan olumlu karşılanacağı yönünde kurulmuştur. Fakat araştırmanın bulgular yaşanan dönüşümün yerel esnaftaki izdüşümünün olumsuz olduğu yönündedir. Olumsuz alginın temelinde mahallenin geleneksel değerlerinin yitirildiği, komşuluk ilişkilerinin zayıfladığı yönünde görüşler yatmaktadır. Dolayısıyla araştırma canlandırma projesinin sosyal sonuçların betimlemeyi ve verilen olumlu/olumsuz tepkilerin nasıl ifade edildiğini ve gerekçelendirildiğini gözler önüne sermektedir.

Anahtar Kelimeler: $\quad$ Mahalle, İstanbul, Kentsel Canlandırma, Rasimpaşa 


\section{Introduction}

The Turkish- Ottoman tradition of mahalle was a social and physical unit, designed as the main functional core of urban life. It follows from this design that the inhabitants of the neighborhood are physically and socially connected. Physically it was the smallest settlement unit including the sacred places (i. e mosque, church or synagogue) primary school, fountain (when there was no infrastructure for water), convenient stores, and coffee/tea houses, Turkish bath, playgrounds (parks). In the Ottoman tradition there are many ways how mahalle is named. Some mahalle were named after the Ottoman Pasha (i.e Rasimpaşa, Piyale Paşa) who endowed their capital for building up the urban infrastructure which made possible via the Waqf system under Islamic law, some are named after an influential religious sheik or leader, some are named after a poet, or a government official' some are named after the previous place of the replaced community (Ergenç, 1980).

Etymologically the term mahalle derives from the Arabic root of hall (halel and hulul) meaning "to inhibit, to locate, to settle"; hence the word mahalle is used in contemporary Turkish derives its meaning from the word mahal that means location, region, and place (Küçükaş̧̧ and Yel, 2003). It is the physical intimacy and shared space that weaves the social fabric into the urban cosmos. Mahalle is the microcosm of urban life in the Ottoman Turkish tradition. Therefore, the mahalle bonds were considered as integral part of a social order, which have been formed by long durée relationships. Primarily a community life was experienced in mahalle along the family bonds (Ergenç 1984, p.9). Current studies on mahalle show that in the Ottoman Empire, cities were based upon neighborhoods and were responsible for satisfying the basic needs, hence the neighborhood administration was at the center of local and central management with its duties and functions (Alver, 2013; Behar, 2003; Cansever, 2016)

Mahalle was also an ethical universe that connects the locals through ties akin to family bonds. That means there are some common values and norms that the community observes. So, this community ethos was considered as the core of the urban social order. Some historical studies on Ottoman urban culture and public administration suggest that it is the 
mahalle that characterizes values such as solidarity and security on a micro scale (Alver, 2013, p.222-223). Nevertheless, it simultaneously creates a discourse of surveillance and control mechanism as well as social, moral and administrative control over people (Alver, 2013, p.222; Cansever, 2016, p.121). Historically speaking, The Ottoman-Turkish mahalle tradition was mainly formed around the religious community centers. Hence people in the neighborhood were relating to each other by "praying under the same roof" (Ergenç, 1984, p.69). Being both a socio-cultural and moral space gives the urban character to mahalle that has been easily transformed into administrative units in a political sense (Uğur, 2015, p.295298).Hence, in this article it can be argued that the Ottoman mahalle can be seen as a liminal space that stands between public and private sphere, hence it is greater than family and smaller than the city.

In this article mahalle and its transforming meanings will be analysed from the point of view of Rasimpaşa's current inhabitants. In order to show this transformation, next chapter will introduce the context of İstanbul's urban transformation, secondly the socio-cultural and historical context of Rasimpaşa will be discussed and then the field work, methodology and categorization of the data (in- depth-interviews) will be presented. Lastly, in the concluding chapter, the findings by the field work will be interpreted in respect to the question of the past, present and future of mahalle.

Remarks on Istanbul's Urbanization Context : It is beyond the scope of this paper to present a comprehensive and diffusive account on the urban history of İstanbul. However, we can argue that contemporary İstanbul, under the pressure of globalization, experienced drastic changes that had a serious impact on local community life. As it is argued in the literature the "beautification of İstanbul" started from the 1950's. In 1956, with a motto of "beautifying Istanbul and glorifying its Ottoman past", Prime Minister Adnan Menderes declared in the press conference that "Istanbul was to acquire an entirely new face and be made into a modern city," (Cumhuriyet, 1956). This "beautification" had irreversible results that the city became an enormous site of construction between 1956 and 1960 (Akpınar,2015, p.56-58) Historically speaking, the chain of processes (i.e gentrification, complex migration dynamics, adjoining and overlapping, 
interlacing revitalization processes) caused by rapid urbanization after the 1950's. Hence the traditional and relatively homogeneous neighborhoods transformed into places that contain various communities settled on top of each other yet not integrated. Its population doubled from about 1 million in 1950 to 2.2 million by 1970 and then grew to 2.9 million in 1980. The population of the metropolitan area grew from 1.1 million in 1950, to 3 million in 1970 and 4.7 million in 1980. Obviously, these transformations had a huge impact on the geography and demography of İstanbul (Enlil, 2011, p.6-8).

It is obvious that these neighborhoods got their share from this transformation by losing their traditional profiles and gradually transforming into locations that are more heterogeneous. In the last 20 years Istanbul has become a global centre of attraction, and along this rise, its historical urban sites have been witnessing the long "urban revitalization and gentrification" processes. The emerging literature on "neoliberal policies and its impact on city planning" suggest that urban space in Turkey entered a new phase during the last decades due to the Act on the "Renewal and Re-use of Deteriorated Historic Building Stock" enacted in 2005 (Act No. 5366) which endows local authorities with new powers to intervene and regenerate historic neighborhoods. It happens where market forces by themselves do not suffice or do not act quick enough to gentrify and transform these settlements (Dinçer, 2011; Enlil, 2011; Lovering and Türkmen, 2011; Tansel, 2019; Uysal, 2015)

As it is noted in the existing literature the revitalization processes are differentiating from the classic gentrification processes where the former take a more community-oriented approach to economic and demographic shifts, and it is more likely to see new businesses in revitalized neighborhoods instead of simply new homeowners. When the historical phases of gentrification and the revitalization of Istanbul are examined, the first examples can be seen in mahalles such as Arnavutköy, Ortaköy and Kuzguncuk that are located parallel to the Bosporus line beginning from 1980s. In 1990 and afterwards, this transformation continued in Cihangir, Galata, Tarlabaşı and Asmalımescit neighborhoods of Beyoğlu. All these settlements which confront gentrification are, in fact, characterized by a multi- cultural society who lived on these lands in the past. (Behar, 2003; 
Coşkun and Yalçın, 2007). After 1980, this fact met the desires of the middle class who were trying to gain a new cultural identity. Therefore, it has become for some people a frequent tendency to long for the previous neighborhood atmosphere which formalized the multi-cultural past of the city and to feel proud of being a resident of Istanbul.

It is remarkable that in these settlements when "revitalization" projects run by private sectors, it is common to observe a change in the social structure of the neighborhood, in most cases the local people with low income end up leaving their neighborhoods as a result of change of value (Şahin, 2013). This seems to be a transition from a communitarian life which is based on both spatial connectedness and historical roots towards the individualistic life which is based on mobility and cosmopolitanism. Academic studies suggest that the example of Rasimpaşa stands out among other renewal projects that are run by private sectors (Şahin, 2013).

In the Rasimpaşa urban renewal project, Kadıköy Municipality and NGO based initiatives named as ÇEKÜL worked together and they both aimed at creating a slow but steady change in the mahalle through participatory development and it seem to be a positive example built upon a participatory model. In Rasimpaşa the municipality supported the foundation of the architectural design atelier that is named as Tasarm Atölyesi Kadıköy (TAK); which is a platform that welcomes citizens, designers, volunteers, students and supporters building national and international collaborations to produce ideas and practices for public good. It is an independent organization; it organizes programs and projects based on volunteering and collaborative work of a variety of designers from different disciplines.

It is apparent that the recent changes enable the formation of a new middle class as a result of the growth in service industry, flexibility in business hours as well as the apparent removal of the home and office distinction by the convenience of the growing digital technology. This new cultural middle class, distinguishing itself from classical middle class, has created its own lifestyle and preferred to reside in old historical neighborhoods paying relatively low rents, which are partly considered as "depression areas" (i.e Rasimpaşa) that has a potential for revitalization. 
The Socio-Historical Context of Rasimpaşa: In Rasimpaşa, there is an apparent cosmopolitan heritage of the old mahalle culture. Here it should be noted that the so-called Ottoman cosmopolitanism is put in question by many scholars (İnalcık 1990; Işın 2008; Boyar 2010) since the İslamic and religious categorizations were demarcating the communities rather than building a harmonius co-existence. Moreover, Rasimpaşa is a district of "multistorey-apartments" that represent the early modernization movement in the Ottoman urbanism. As one can see at the first glance the urban texture in Rasimpaşa is dense, formed by approximately multi-storey apartments. The spatial structure of the district (slopes and elevations) has huge contribution in this density; their backyards and empty areas between apartment blocks and this forms a multi-sectional neighborhood texture; the historical brick apartments are decorated with frontage embellishments and are influenced by Art Nouveau. Reinforced buildings in the neighborhood are constructed between the years 1950 - 1970. Hence the "multicultural non-Muslim texture", inherited from the Ottoman Empire enduring the initial years of the Republic, in time gave way to a social-culture structure dominated by Muslim Turkish population. The famous apartment buildings Valprede, Menase and Kehribarji were built by non-muslim communities between 1905 and 1908 (Atılgan, 2017). Due to the historical value Rasimpaşa has benefited from the privilege of being a "protected area" and therefore this area is suitable for revitalization rather than rebuilding or gentrification. Today these apartments are still standing and being home to working class families who came from Eastern part of Turkey. In this context Rasimpaşa, having grown especially by internal migration (from Bingöl, Konya and Blacksea Region) and lowincome group has concentrated here until the 1990s (Türkmen, 2015).

The most remarkable historical buildings in Rasimpaşa belong to three different religions; Rasimpaşa Mosque, Agios Georgios Eastern Orthodox church and Hemdat Israel Synagogue. Each of these religious buildings have a historical and cultural role hence they complete the narrative of Ottoman cosmopolitan mahalle culture. Most of the historical apartments of the old Rasimpasa district are in fact the apartments once constructed for the lodging of German and Italian personnel during the construction of Haydarpaşa Train Station.Haydarpaşa Train Station was constructed in 
1909 by the Anatolian Railway [CFOA] as the western terminus of the Baghdad and Hedjaz railways, has become a symbol of Istanbul and Turkey and is famous throughout the Middle East (Atılgan, 2017).

As a result of the revitalization processes, new cultural middle class (artists, gallery owners, art directors and journalists, Erasmus students and university lecturers, etc.) preferred this region as their residence. Some of these newcomers also started their own business (as cafe, art studios, craftwork shops). In this way the upper middle class also joined in the mahalle's population, which was composed of working class and lower middle class before. Considering its central location (geographical proximity to the Ferry docks, Marmaray, Metro, Metrobus lines), historical value and the rent scale, Rasimpaşa became an attractive spot for international visitors.

According to the data provided by the Turkish Statistical Institute (Türkiye İstatistik Kurumu -TUIK 2017), the population of the Rasimpaşa neighborhood is 14,016 (6671 male and 7345 female). Municipality's official discourse emphasizes that the vitalization project conducted by the Foundation for the Protection and Promotion of the Environment and Cultural Heritage [ÇEKÜL] and Kadıköy Municipality (2010-2013) gives weight to "mahalle culture" and looks out for protecting the heritage without interfering into the living habits of the residents (Municipality Social Service, 2020).

However, in this article the revitalization will be considered from the point of view of the present inhabitants, hence the article focuses on how the inhabitants perceive the transformation of their mahalle, it hypothesized that the local people would welcome the revitalization due to basic pragmatic reasons, for example they would perceive it positively as long as they economically gain from these processes. However, it could also be the case that the locals would take a more conservative attitude towards change and perceive it negatively. It will be shown in the concluding part why and how it is perceived negatively. 


\section{Method and Sample}

The field work that was conducted in Rasimpaşa in 2018 lasted for 6 months and it focused on reactions by the local people mainly the traditional shopkeepers (Total 40 people, 30 male 10 female) who lived here more than 30 years. The examplary/sample discourses quoted here will be coded as numbers to keep confidentiality (i.e 1nterviewee 1 , grocery shop owner). 40 interviews for this study are conducted in 2018-2019, JuneJanuary in Rasimpaşa, Kadıköy. In this article I refer to the sample of the expressions by nine (9) interviewee as they represent the positive and negative responses Below Table 1. shows the coded list of interviewees, their professions and dates of interviews.:

Table 1. Coded list of interviewees according to their professions

\begin{tabular}{lll}
\hline Code & Profession & Date of Interview \\
\hline Interviewee (1) & Grocery shopkeeper & 22.06 .2018 \\
Interviewee (2) & Stationary shopkeeper & 30.07 .2018 \\
Interviewee (3) & Community house manager & 19.08 .2018 \\
Interviewee (4) & Electronic Repair shopkeeper & 22.08 .2018 \\
Interviewee (5) & Photobooth owner/Photographer & 12.10 .2018 \\
Interviewee (6) & Neighborhood House Manager & 08.09 .2018 \\
Interviewee (7) & Tailor & 27.11 .2018 \\
Interviewee (9) & Shopkeeper & 16.01 .2019 \\
\hline
\end{tabular}

The semi-structured in-depth interviews concentrate on three simple questions. 1) How was mahalle life in the past? 2) What are the changes in mahalle today? 3) How will it be in the future?

First question addresses the historical meaning and past experiences, second question addresses the present-day perception of change, the third question addresses the future vision of the residents, which could be also decisive for their vision of Rasimpasa after the revitalization. These questions will also constitute the chapters of the present article. Regarding the first question majority of the interviewees define the concept of mahalle with the following words: "Being tight-knit", "Collective life", "Muslims and non-Muslims together". Regarding the second question there are positive and negative responses to the transformation of Rasimpasa. Regarding the third question about the future majority of the interviewees are pessimistic and highly critical the loss of traditional mahalle culture, however there are a few positive examples that suggest the traditional culture 
will be a new home for the newcomers who that could adapt themselves to the existing tradition. Each question follows a timeline so that we can see how the interviewees see the past, present and the future of Rasimpaşa.

\section{Findings}

Those Were the Days: Neighborhood as A Big Family: As far as the history of mahalle is concerned the word "nostalgia" is inescapable for its residents. When it is asked "how was life back then" most of the interviewees underline the presence of non-Muslim communities. Even though there are different religions communities standing side by side in the same mahalle, cooperation among different cultures are especially highlighted by the interviewees. When they recall the traditional characteristics of mahalle, the following words recur: "tea and chat at the doorsteps", "not locking doors at night", "helping each other in childcare", "everyone knowing everyone", "mutual family visits in the evenings", "uniting Muslims and non-Muslims during funerals and religious holidays", "morning salutations", "security", "watching out each other". The abovementioned expressions emphasize mutual social awareness and transparency. According to one interviewee (1), when " 500 people share grief of a single person also, 500 people share the joy of a single person, this is "mahalle". It is the place where "all become one". This emphasis of unity, such as "becoming one big family when necessary" is the basic theme of nostalgia regarding the mahalle life. An interviewee (2) says: "If my neighbor next door is not going to heal my wound then, for what good is he/she here".

Hence from the perspective of the locals, sharing grief and joy brings forth a kind of "neighborhood as a moral universe" where common values and expectations are set and cultivated. Referring to the old times, \%90 of the interviewees mentioned 'community responsibility' and 'respect for others needs'. For example, when non-Muslim shopkeepers who made the first sale of the day in the morning usually send their second customer to the nearest Muslim shopkeeper that have not yet made the first sale. Similar communal responsibility is apparent in cooperative action in childcare. When the interviewees recall their childhood memories, they 
recall playing in the street all day long and eating lunch in each other's tables.

While responding to the second question about the present situation of mahalle, $\% 100$ of the interviewees underlined the dramatic decrease of non-Muslim population (Greek, Armenian and Jewish) who were the integral part of the mahalle and who made a special contribution to the spirit of solidarity. All interviewees feel nostalgic about the "old lifestyle" approximately 30 years ago. Especially, solidarity in times of funerals and religious holidays are still a nostalgic reminiscence for the old residents. As Interviewee 3 says: "We did not attend the daily religious ceremonies, but we did go to the funerals. Whole neighborhood attended the funeral of Solomon and Dr. Vita at the synagogue. But why is the door of the synagogue closed today? Because they feel not secure" (K. F). "There were attacks, there is no security of life; doors were closed when they attacked (Synagogue) ceremonies... I must confess that we are a bit barbarian".

Here it should be noted that the interviewee (3) refer to the three terrorist attacks in İstanbul on Neve Shalom Synagogue in 1986, 1992 and 2003. That is an important point that these attacks and political situations make people insecure and distant from each other today. Interviewee (1) tells that "the church bell used to ring every day. It does not today... there was Monsieur Yanni; he owned a five-store shop, a draper, and he was loved by everyone. He continues and says 'During the "Cyprus Peace Operation" in 1974 Yanni was afraid sold everything and disappeared ".The operation mentioned by (interviewee 1) here refers to the Turkish military operation on Cyprus that was launched on 20 July 1974, following the Cypriot coup d'état on 15 July 1974. This event had a serious impact on Turkish Greek relations (Stavrou, 2011: p.130).

As one can easily follow, the high politics on the international level had its consequences on the micro politics as well as in mahalle level. Though today these non-Muslim neighbors are remembered with nostalgia it would be too naive to think that the Turkish citizens of this mahalle was immune to the effervescent nationalism at that time. There could also be some local cause for the insecurity of people like Mr. Yanni. When asked, $\% 100$ of the interviewees underline the positive side of the intercommunal relations as one can see in the following expressions: 
- "We learned Greek while living with them, we used to say good morning "kalispera" in Greek. "When they go Church on sunday times it was like a parade. Unfortunately, they are gone, and the tradition is dead." (Interviewee 1)

- "We played in the garden of Synagogue; we had Orthodox neighbors; their garden was well trimmed; I saw aquarium fish for the first time in their garden...The doors were always open; our neighbor would bring gavurdağı salad and my mom would send them deep fried pastry. They celebrated Easter and gave us cases of eggs. They were decent people". (Interviewee 2)

- 'Our Jewish neighbor had a fridge. I used to sell water down in Kadıköy, and they were helping me making ice so that I can keep the water cold." (Interviewee 4)

- "We had Armenian neighbors, everyone was saluting each other; some afternoons they bake pie and my mom bake special pastry (pufböreği) then they together drink tea on the doorsteps" (Interviewee 5)

The local memories of Rasimpasa residents bear many characteristics like the people of other historical neighborhoods (i.eKuzguncuk, Teşvikiye) who had preserved the same Ottoman cosmopolitanism for some time after the foundation of the Turkish Republic in 1923. Academic research on these historical mahalle culture suggest that in the mindset urban middle class there has been a strong emphasis on the lost "cosmopolitan" Istanbul (Neyzi, 2009; Mills, 2004). However this attitude is transforming rapidly with new immigrations and Istanbul's new silhouette after the 2000's: "Portrait of an ideal but lost city, where diverse but urban communities live in peace, is featured in many cultural artifacts such as autobiography, documentary, TV series, novels and cinema" (Mills, 2004: p.367-394). According to Neyzi (2009) the epitome of sympathy displayed by the urban middle class towards non-Muslim minorities (or their ghosts in the city) lies within the class and cultural alliance formed against recent migrants who came from the countryside. Urban middle class, today identifying themselves with the minorities fictionalized as "old Istanbulites' ', is composed of Muslims bourgeosie that gained their current position with the opportunities of the Republic. Therefore, it can be argued 
that the locals of Rasimpaşa harbor a similar nostalgia that Neyzi and Mills have mentioned.

\section{Neighborhood Today: "Open to the World, Yet Closed to Neighbors": As} it was mentioned before, with the revitalization process and settling of the new middle class that comprises artists, journalists, foreign and local students, Rasimpaşa's profile has changed; the most important triggering event was the "Yeldeğirmeni Neighborhood Vitalization Project" conducted with the partnership of ÇEKÜL Foundation and Kadıköy Municipality since 2010. In this context for example, MURAL-IST being the first event in Turkey for painting building facades has brought an utterly different ambiance to the spatial appearance of the neighborhood. The Yeldeğirmeni Wall Art Festival was held within the scope of "Yeldeğirmeni Neighborhood Revitalization Project", and the neighborhood became an attraction center for both local and international artists. Mural festival was a good example in observing how global trends and courses were represented locally (Mimarizm, 2018).

Therefore, Rasimpasa (Yeldeğirmeni) being articulated into the wall art trends worldwide has become a new value in terms of global scale.Similarly, another dynamism transforming the neighborhood is the geometrical increase in socialization areas (Artist workshops, event venues, Yeldeğirmeni Art Center, Design Studio Kadıköy and generally cafés with the concept of "Italian style"). Especially cafés offering work space and wireless internet have become asocialization area preferred by the students and young people who work from home. \%10 of the interviewees state that newcomers brought a new joy to the neighborhood and say that, "the newcomers adapted to us, and we did not adapt to them". The $\% 90$ of the interviewees are unhappy with the newcomers. For them it is mainly the issue of "internationalization" and "unfamiliarity" of the newcomers that caused the disturbance and negative perception.

In regard to rent scale in Rasimpaşa, five years ago it was possible to find a studio-flat at a reasonable price for a student budget, however in five years TRY/square meter of real estates increased to 104.5\% - (Zingat, 2019). This increase has attracted many real estate investors to the region. Some investors renovated the old apartments and turned them into international youth hostels which has attractive prices for moderate 
budgets. Moreover the global accommodation networks such as Airbnb contributed to the branding of Rasimpaşa as an international spot for young travellers.( Uzgören and Türkün,154-170). Some of the interviewees express their disapproval of the constant flow of people in the mahalle, highlighting that security. and peace of the mahalle is disturbed. Most of the complaints of the residents underline the following words: "degeneration", "alcohol consumption on the streets", "littering", "not saluting", "not knowing each other", "cosmopolitan life", "insecurity" and "immoral manners.

The interviewee (5) expresses his comment in the following way: "Ground floors of the apartments turned into cafés or art studios, it is fine to have such places but if they arouse chaos, if the sidewalks are occupied, if there is no respect for each other, if people throw their cigarettes on the streets then we will not tolerate this. The rents of shops have increased by $90 \%$. They come and open workshop ateliers, artists do sculptures, sell them at a high price, hence they can pay high rents. Putting the money issues aside, these artist groups don't mix in the mahalle. They live where they work, inside their atelier, use the art studio as lodging; there are even rooms which are rented daiy. They call it private life, what the heck is that?" (Interviewee 5).

Another interviewee (6) expresses his ideas in the following way: "“'What happens to our mahalle when families go away? If 15 students are living in a home, then there is no social touch with the neighbors. No komşu (neighbor) no mahalle. Families do not pay visits to each other, we used to gather in one's house every evening, we would eat popcorn, there was no TV, and everyone would sleep around 10:30 pm. You can see this old lifestyle nowadays only in small towns of Anatolia" (Interviewee 6).

The selected discourses above show the negative sentiments that seem to be rising between the old and new Rasimpaşa people. Thereby, lifestyle differences between them constitute problems such as who should adapt to whom? As it can be traced from the expressions such as "they adapted with us, not vice versa" or "we won't be amahalle anymore if no one knows each other" indicate that the local people feel that their mahalle life is at stake.

As the interviewee (7) says: "In the 1970s non-Muslims were the majority here, they were so polite.They would say thank you even when they 
give you money. They were orderly and tidy; even the laundry was dried in back balconies not in the front. The cultural mosaic has shattered, spiritual richness has gone; People used to know each other, now no one will be aware if you have a funeral, no one will send them traditional food. Half of the neighborhood used to go for the prayers, but not anymore" (Interviewee 7).

In this context one can see that the diversification and mobility of people in terms of class, lifestyle, nationality, causes unrest among the locals. As it is expressed by interviewee (5):"This liberal cosmopolitan lifestyle' and so called democracy is not good for the mahalle: Democracy is like an oversize shirt that does not fit us; there must be a bit of fear besides love; freedom, democracy, aimlessness are a bit over the top of us. In the past, evil was rare but now the good is rare. Insensitivity towards neighbors will bring the end of mahalle; there is no faith,no trust. We were really poor back then; I would like to go back to those old days because we overcame poverty but overpowered by wealth" (Interviewee 5).

Though there is a negative tendency towards the newcomers and the new profile of the mahalle, there are also positive responses regarding the internationalization of the people of mahalle. Erasmus students, artists who come from different countries using Airbnb links and global housing networks produce the "good guests" of mahalle. As interviewee (8) and (9) say:"We become cosmopolitan. For example, yesterday, a Peruvian and Danish got acquainted in my shop. Marmaray (train) also had an impact, the number of student housing has increased here. We do not complain about them. We get acquainted here. There are artists, organizing workshops; they invite us to their events. One time, one of these artists guys distributed flour halva (un helvasi) and told that his mother had passed away. They share it with every shopkeeper here, it means that they are mixing in tomahalle, not vice versa" (interviewee 8).

Another interviewee supports the positive sentiment in the following way: "There are artists in the neighborhood. We got acquainted with Erasmus students. They are influenced by our mahalle life. They speak Turkish, we are surprised by it. We are happy with it". (Interviewee 9)

Looking into the Future of Neighborhood: The third question of the fieldwork interviews, "the future of mahalle?" is reserved for collecting public 
opinions regarding the future. Real estate companies make the projection that Rasimpaşa, transforming gradually in the last five years, will be a rising star for the young urban alternative lifestyle (Zingat 2019). Socio-economically, it is in category (A). Category A means that the $36.5 \%$ of the population has a university diploma and the ratio of 15-44 age range in the general population is $57.3 \%$. The future projections made by the real estate database services (i.eEndeksa 2019;Zingat 2019; Yuvako 2020) suggest that Kadıköy and Rasimpaşaarerising trends in the field ofreal estate investment;it is also the case in the formerly revitalized neighborhoods of İstanbul such as Beyoğlu and Cihangir.

It can be clearly seen in the discourses of the interviewees that Rasimpaşa would resemble Beyoğlu and Cihangir soon. Beyoğlu and Cihangir represent the examples of formerly revitalized regions that are mostly populated by the upper middle-class intellectuals and artists today. This indicates that mahalle in the old sense is replaced by a more individualistic, urban and cosmopolitan lifestyle. While groceries and repair shops transform into cafés, hostels, and art studios, young, unmarried profile will populate the mahalle, hence a new Rasimpaşa -with its new problems- will be born. Regarding the negative impact of the transformation interviewees conveyed issues such as lack of familiarity, intimacy, security. Moreover the $\% 90$ of the interviewees express the opinion which suggests that the technological tools deprive physical communication and sense of collectivity. An important detail emphasized by the interviewees is that newcomers of the neighborhood are " open to the globe but careless to their neighbors".

The most significant indicator is the café culture, which made a huge change in the social life of the neighborhood. As expressed by interviewee (8) "being neighbors in traditional sense is not properly experienced by the young generation; why should we go to those expensive coffee houses and pay for it while we can have a cup of coffee with our neighbor?" This sentence is a clear indication that locals have hard time to conceive the mindset of the new middle class who go to a cafe to work or socialize. Once upon a time, neighbors in the Rasimpaşa "mahalle" used to sit on chairs at the doorsteps, sharing tea and homemade pastries but now, this has moved indoors in apartment buildings and transformed into 
"making evening visits at home". Nowadays, a brand-new format has developed with the cafés opened at every corner. Mahalle's social area has gained a heterogeneous and cosmopolitan characteristic.

\section{Conclusion}

To sum up, this article attempted to approach the mahalle culture as a concept that is inherited from Ottoman Empire and it tried to analyze how "mahalle" transformed in contemporary İstanbul. In order to understand how the locals, perceive the revitalization and its social implications this article presents the field work data that was obtained from the in-depth interviews with the local shopkeepers who had lived in Rasimpasa more than 30 years. In this research it was expected that the locals who economically gain from the process would perceive the changes in a positive way. However, it turned out to be the case that in the eyes of the locals, the newcomers (upper middle-class profile and "foreigners" coming via global networks) make the traditional mahalle culture more vulnerable. For the local shopkeepers, the changes coming along the revitalization caused discomfort, insecurity and estrangement. As $90 \%$ of the interviewees expressed their discontent, only $10 \%$ of the interviewees see it from a positive lens. Those who take it positively are in the opinion that their "mahalle" stands as a place for global encounters and it is good for future. Within this frame, mahalle can be considered as liminal space not only by being family and urban community but also by means of interaction between old and new, new synthesis and hybridizations. From the negative side which represents the $\% 90$ of the interviewees the recent transformations will end the mahalle in the old sense as they know, as a transparent,social and physical unity as well as a moral universe. As it can be observed due to the changes in this mahalle, the traditional family life is decreasing, steady communitarian life is decaying, instead global mobility and human flow is increasing, international housing market is rising, working hours and and lifestyle of the young generations are changing.

As a result of this micro scale research, one can argue that though Rasimpaşa is officially presented to be a positive participatory model for revitalization process in İstanbul, from the eyes of the local shopkeepers it seems to have some negative consequences regarding mahalle culture. 
This could be meaningful for the future discussions on three basic considerations. If mahalle culture is considered as a cultural heritage to be preserved in the urban context, the following points are to be reconsidered:1) Participatory models in revitalization process needs to take the local reactions into account 2)Not only economic but also socio-cultural projections concerning local settings is vital for the future of mahalle.3) The social impact of international real estate market on the local level needs to be considered.

Regarding the first level, further field studies are needed to compare different models and experiences to view the phenomenon from local level. In the context of conserving the cultural heritage, the social impact evaluations and field work gain special importance since the local reactions can be considered for constructing a sustainable revitalization process without causing any negative reaction in the local community. Although the interviewees mention about the non-Muslim communities such as Christian or Jewish neighbors who significantly differ from the Muslim faith, they do not narrate their differences as an exclusive one. However, it seems to be the case that the interviewees tend to develop a thicker concept of the "strangeness" towards the newcomers (upper middle class and international visitors) compared to the non-Muslim communities in the past. Connecting first and the second level it is crucial to rethink whether the locals longing for the past is a mere nostalgia, fueled by selective memories of the harmonious good old days with the non-Muslim neighbors or could it correspond to a conservative communitarian call against the "ruthless cosmopolitanism" that pay reference to the idealization of the family and neo-conservative moral ground that can be found in religious communities. Moreover, regarding the third level described above, the indicators of the real estate market shows that Kadıköy and Rasimpaşa is an attractive investment for the newcomers as well as foreign internationals (Zingat 2020). If this region continues to be an appealing place for investment, this means that revitalization of mahallemust absorb more cosmopolitan encounters than before.

Hence the discussion over mahalle paves the way for further sociological debate over new urban belongings, new encounters and new understanding of shared social and physical spaces. Borrowing an analysis by the prominent sociologists Urry one can argue that the modern urban 
identifications deconstruct the classical meaning of settlement and identification processes (Urry, 1999: p.288). Hence, the modern urban identity has completely reversed the traditional identification processes. In one respect, existence of new public locations, such as cafés, hostels, where people experience a specific sense of privacy within the public space transforms the spatial experience i.e. juxtaposition of people in a café, or a specific corner in the neighborhood turning out to be a hangout place for residents as well as for the tourists. All of these in urban scale seems to serve to the development of atomic identities that are extraordinary as expressed in different kinds of urban belongings. Therefore, Rasimpaşa and other revitalizations projects can be discussed further as samples that produce multiple kinds of belongings and multilayered social experiences for the new and old Istanbulites.

\section{References}

Akpınar, İ. (2015). Urbanization represented in the historical peninsula: Turkification of Istanbul in the 1950s. M.Ö. Gürel (ed.), Mid-Century Modernism in Turkey: Architecture Across Cultures in the 1950s and 1960s içinde p.56-84(New York and London: Routledge.

Aksoy, A. (1996). Küreselleşme ve İstanbul'da istihdam. İstanbul: Fes.

Alver K. (2013). Mahalle: Mahallenin toplumsal ve mekânsal portresi. İstanbul: Hece yayınları.

Atılgan,A. (2017). Evvel zaman içinden yel değirmeni. İstanbul: K-İletişimyayınlari.

Aytaç Ö. (2007). Kent mekânlarının sosyo-kültürel coğrafyası. Fırat Üniversitesi Sosyal BilimlerDergisi, 17(2), 199-226.

Behar C., (2003). A neighbourhood in İstanbul. NY: State University of New York series.

Boyar E. and Fleet K. (2010). Social history of Ottoman İstanbul. Cambridge: Cambridge University Press.

Cansever, T. (2016). İslam'da şehir ve mimari. İstanbul: Timaş.

Coşkun, N. and Yalçın, S. (2007) Gentrification in a globalizing world, case study: İstanbul, Rotterdam, ENHR 2007 International Conference Sustainable Urban Areas, 25-28 June 2007.

Cumhuriyet (1956, 13 Ekim). Başvekil beklenen basın toplantısını dün yaptı, Retrieved from: https://egazete.cumhuriyet.com.tr/ 
Çeker A. and Belge R. (2015). İstanbul'da kentsel dönüşüm kapsamında gerçekleşen bir olgu: Soylulaştırma. Türk Coğrafya Dergisi 65, 77-86.

Demirrel, T. and Serdaroğlu S., N. (2019). Kentsel dönüşümde sosyal etki değerlendirmesi: Sümer Mahallesi kentsel dönüşüm projesi. Bartın Orman Fakültesi Dergisi, 21(2), 350 - 368. DOI: 10.24011/barofd.569896

Düzbakar, Ö. (2013). Osmanlı döneminde mahalle ve işlevleri. U.Ü. FenEdebiyat Fakültesi Sosyal Bilimler Dergisi, 5(2), 99.

Ergenç, Ö . (1984). Osmanlı Şehrindeki "mahalle"nin işlev ve nitelikleri üzerine . Osmanlı Araştırmaları , 04 (04). Retrieved from https://dergipark.org.tr/tr/pub/oa/issue/10973/13129.

Ergenç, Ö. (1980). Osmanlı şehirlerinde esnaf örgütlerinin fizikî yapıya etkileri. (Eds. Osman Okyar and Halil İnalcık). Birinci Uluslararası Türkiye'nin Sosyal ve Ekonomik Tarihi Kongresi Bildirileri, Ankara.

Enlil, Z. M. (2011). The neoliberal agenda and the changing urban form of Istanbul, International Planning Studies, 16(1), 5-25.

Işın E. (2008). Everyday life in İstanbul. İstanbul: Yapı Kredi yay.

Inalcik, H. (1990). Istanbul: An islamic city. Journal of Islamic Studies, 1, 1-23.

İnalcık H. (2011). Devleti 'Aliyye Osmanl İmparatorluğu üzerine araştırmalar I. Türkiye İş Bankası Kültür Yay., İstanbul.

Küçükaşçı, M. S. and Yel, A. M. (2003) TDV İslam ansiklopedisionline: https://islamansiklopedisi.org.tr/mahalleDate of Retrieval: 23.10.2020

Mills, A. (2004). Streets of memory: The kuzguncuk "mahalle" in cultural practice and imagination. PhD Thesis, University of Texas at Austin, Texas,USA.

Mimarizm-Journal(19.06.2018)Accessed-online:

https://www.mimarizm.com/etkinlikler/sergiler/mural-istanbul-festivali-2018_129266

Date of Retrieval: 13.08.2019

Neyzi, L. (2009) Eski İstanbul'un şehir kültürünü hatırlamak: Yaşanmışlık, bellek ve nostalji, Eski İstanbullular, Yeni İstanbullular, Murat Güvenç (yay. haz.)içinde (78-83) İstanbul: Osmanlı Bankası Arşiv ve Araştırma Merkezi.

Öncü, A. (1997). The myth of the 'ideal home' travels across cultural borders to İstanbul (Eds. Öncü, A. and Weyland). Space, Culture and Power: New Identities in Globalizing Cities, London: Zed Books.

Stavrou, M. (2011). Resolving the cyprus conflict: Negotiating history. Palgrave Macmillan 
Şahin A. S. (2013). Kültürel miras alanlarının dönüşümünde yeni bir yaklaşım. Unpublished Master Thesis. İstanbul Bilgi University, İstanbul.

Tansel, Cemal B. (2019). Reproducing authoritarian neoliberalism in Turkey: urban governance and state restructuring in the shadow of executive centralization. globalizations, 16(3), 320-335.

Türkiye İstatistikKurumu, [TÜİK] (2015), Demographical Data, Accessed online: www.tuik.gov.tr Date of Retrieval: 05.05.2018.

Türkmen Z. (2015). The cultural transformation of yeldeğirmenineighborhood. (Unpublished Master Thesis). İstanbul Bilgi University: Cultural Studies,Istanbul.

Uğur Y.(2015) Osmanlı şehirleri ve şehirleşmesi. Osmanlı İmparatorluğu'nda Çevre Ve Şehir, İstanbul Medeniyet Üniversitesi and Çevre ve Şehircilik Bakanlığı yayını, 295-298.

Ünsal, B. Ö. (2015). State-led urban regeneration in Istanbul: Power struggles between interest groups and poor communities. Housing Studies, 30(8), 1299-1316.

Urry, J. (1999). Mekânları tüketmek. (Trans. R.G Ögdül) İstanbul: Ayrıntı Yayınları.

Wolf, M. (2005 June). Turkey - rising star? Paper presented at the Emerging European Real Estate Markets: Trends, Challenges \& Opportunities, Urban Land Institute Conference, Istanbul.

Zingat (2019) Rasimpaşa-Kadıköy Regional Report. Accessed Online https://www.zingat.com/kadikoy-rasimpasa-bolge-raporu Date of Retrieval: 23.10.2020

\section{Citation Information}

Durgun, S. (2021). The Changing Meanings of Neighborhood in Modern Istanbul. OPUS- International Journal of Society Studies, 18(40), 2009-2029. DOI: 10.26466/opus.872573. 